\title{
Research on Improvement of Irrigation Systems, Mining and Crops in Azerbaijan
}

\author{
RAE ZH Aliyev* \\ Institute for soil science and Agrochemistry of the Azerbaijan National Academy of Sciences, Azerbaijan
}

Submission: October 11, 2018 ; Published: November 21, 2018

*Corresponding author: RAE ZH Aliyev, Institute for soil science and Agrochemistry of the Azerbaijan National Academy of Sciences, Azerbaijan

\begin{abstract}
The experimental work carried out by us in the objects of study in Shamakhi, the Tartar, Zagatala, Guba and Ganja on irrigation of soybean, sugar beet, maize and tobacco, orchards and a vineyard can give an estimated average the intensity of the rain $(\mathrm{mm} / \mathrm{min})$ under irrigation norms $300-500 \mathrm{~m}^{3} / \mathrm{HA}$, depending on the soil types: Sandy-0.3-0.4, light loamy-0.2-0.3, middle and heavy loam-0.1-0.2. Studies have shown that the wide production verification of this irrigation technology, taking into account the recommended intensity of rain, will clarify the technical-economic indicators and conditions for the use of micro-irrigation. As a result of the adjustment of irrigation regime, it was found that under irrigation norms $300-420 \mathrm{~m}^{3} /$ ha of soil soaking on insignificant depth $(20-30$, sometimes $40 \mathrm{~cm})$. Low speed absorption of topsoil and large biases have provided significant surface relief $(30 \%)$, increasing from irrigation to glaze. soil moisture Increase was only $100-$ $300 \mathrm{~m}^{3} /$ ha.
\end{abstract}

Keywords: The speed of absorption; Irrigated; Irrigation norm; Moisture-holding capacity; Furrow; Root system

\section{Introduction}

The main requirement for artificial sprinkling is the creation of rain with an intensity not exceeding the speed of absorption of water. Various factors significantly affect both the choice of method of irrigation, and irrigation equipment. One and the same factor may be significant in one way and not have the special meaning otherwise. Despite this, all of these factors and conditions are closely interact with each other.

At the site in the village of Malham Shamakha district of the Azerbaijani Republic conducted a study mikro-sprinkling irrigation system on medium and large slopes in deep groundwater level. There were studied the effects of watering fruit trees sprinkle apparatus type IDAD on territory of skilled plot MEI Sri "erosion and irrigation MINISTRY OF AGRICULTURE of the Azerbaijan Republic with an area of 4.82HA, as well as on the territory of Ganja RACN in PIC. Bagmanly with an area of 1.45 hectares during the period 2004-2007 BC. in irrigated lightchestnut soils with extreme moisture capacity $3000-3100 \mathrm{~m}^{3} / \mathrm{ha}$ and grey soils with deep groundwater occurrence on the Alazani Valley in Zakatala district between 2004-2006BC. Conducted 99 irrigations (500-650m $3 /$ ha) with irrigation norm $1890 \mathrm{~m}^{3} / \mathrm{ha}$. Only the top layer of soil is humid (28-30) [1-5].

In mid-July, the humidity $30 \mathrm{~cm}$ soil layer was reduced to $40 \%$ (OPV), and at the beginning of September to $40-60 \%$ (in metre layer), resulting in under drying and reduce crop silage corn and winter wheat. On the control plot (five irrigations on furrow with irrigation norm of about $16000 \mathrm{~m}^{3} / \mathrm{HA}$ ) moisture was $80-100 \%$ PPV.

As a result of the study, it is recommended to optimize the irrigation norm, the amount of irrigation and the reduction of the inter-field periods; pointed out the desirability of sprinkling with the use of design of various modifications of micro-absorption in areas where this irrigation furrow was difficult, and sometimes impossible [4,6-11].

Table 1: On site research, selected "posting area with more closeknit plantlets, the total area of $4.82 \mathrm{ha}$, located in the District of RANN Guba MEI Lips.

\begin{tabular}{|c|c|c|}
\hline Options & Width Row Spacing, Cm & $\begin{array}{c}\text { Density of Standing Plants, } \\
\text { Thous. PCS/Ha }\end{array}$ \\
\hline (I) & $4.5-5.0$ & 198 \\
\hline (II) & $2.8-3.0$ & 280 \\
\hline (III) & $2.2-2.5$ & 383 \\
\hline
\end{tabular}

Sri "Erosion and irrigation» MA AR with participation of the author continued experiments on irrigation apparatus IDAD, etc. modifications of mikro- irrigation equipment of various kinds of crops on the newly reclaimed rainfed lands, i.e. in the example of research objects, which were laid on the study of experiences for the development of irrigated agriculture in mining areas; GubaKhachmaz, Ganja-Gazakh, Karabakh, Shirvan, Sheki-Zagatala and others. regions of the republic. It should be noted that in the areas of the experiment, soil-deformed, Loeboursky, loamy 
(gray), etc. With different characteristics of the soil. In all these areas, the experiment investigated the depth of groundwater. In this case, it is planned to increase the density of plants and not to conduct between the rows of processing. On site research, selected "posting area with more close-knit plantlets, the total area of $4.82 \mathrm{ha}$, located in the District of RANN Guba MEI Lips (see Table 1).

For vegetation period, irrigation 94 was held with the estimated irrigation norm $4590 \mathrm{~m}^{3} / \mathrm{ha}$, that did not provide normal soaking the soil. Height of plants of fruit trees (about $5.0 \mathrm{~cm}$ ) and area on a path of wetting $\left(8-11 \mathrm{~m}^{2}\right)$ that was lower than the irrigation by furrows $[4,9]$. The root system has spread in a layer to a depth of $2.0-3.0$, and when the channels selected watering-in a layer deeper than $3.0 \mathrm{~m}$.

Hydration of this small area was uneven, and the Apple tree yields more wet areas in Guba region amounted to 210.9 centner/ha and $189 \mathrm{~kg} / \mathrm{ha}$ at Ganja RCAN and the withered accordingly 147.3 and $113.9 \mathrm{~kg} / \mathrm{ha}$ [4].

The absence of crop treatments with narrowed spacing resulted in severe soil compaction and water permeability reduction, increased surface runoff when watering. The increase in density of standing has not had a significant impact on the oppression of the weeds.

The development and growth of fruit (apples, pears, peaches, persimmons, etc.) trees were soil relative humidity 20-40\%, wetting does not exceed $25 \mathrm{~cm}$. Later in the Republic mikroirrigation IDAD type system and others, proposed to the serial production, nowhere else for sprinkling is not tested. Originally in 2003г. We chose an experienced pilot plot on the territory of Guba district in MEI RCAN Lips, on the foothills of Sahdag, with a total area of 2.8 hectares, and MEI Ganja RCAN PIC. Bagmanly with an area of 1.45 hectares. [4,9,10,].

The soil of these middle massive arrays $(30-40 \mathrm{~cm})$, biases more $-0.02-0.025$. Carrying out irrigations on furrows is difficult, due to the difficult terrain of the territory. So here was planned sprinkler irrigation with small norms using various modifications and micro-sprinklers IDAD $[11,12]$.

Water supply for irrigation of these sites was carried out from the hydrants, established through $85,120,200$. As a result of the adjustment of irrigation regime, it was found that under irrigation norms $300-420 \mathrm{~m}^{3} /$ ha of soil promachivaetsja on insignificant depth (20-30, sometimes $40 \mathrm{~cm})$. Low speed absorption of topsoil and large biases have provided significant surface relief (30\%), increasing from irrigation to glaze. soil moisture Increase was only $100-300 \mathrm{~m}^{3} / \mathrm{HA}$. Small irrigation standards require private irrigation (via 5-6). Submission of large irrigation norms (600$700 \mathrm{~m}^{3} /$ ha or more) is difficult because of the intensity of rain $(2-3 \mathrm{~mm} / \mathrm{min})$ and speed of absorption of water into the soil [ $4,8,13,14]$.

Large drops of rain destroy soil structure, and the upper $2-3 \mathrm{~cm}$ burrow; the speed of absorption is reduced, causing a superficial reset. Then skilled plot was organized in microsprinklers area of 1.5 hectares for irrigation of soybean, sugar beet, silage corn, fruit trees, on the territory of the AIA Sri "Farming" Terter district with an area of 1.5 hectares. Soil section (with a total area of over 30 hectares)-medium loam, biases of 0.005 (Figure 1).

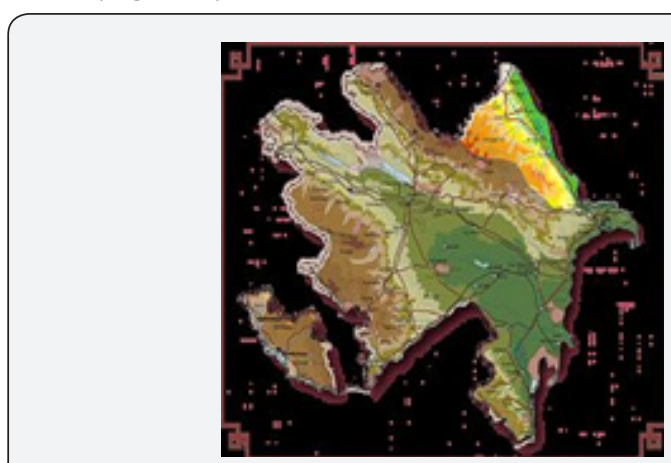

Figure 1: The main requirement for artificial sprinkling is the creation of rain with an intensity not exceeding the speed of absorption of water.

And so, in 2004, have been implemented with glazes irrigation norm $3700-4200 \mathrm{~m}^{3} /$ ha (irrigation norms from 350 to $550 \mathrm{~m}^{3} /$ ha). Humidity in the $60 \mathrm{~cm}$ did not fall below $60 \%$ of the SWP, The upper boundary of the articulation was (after irrigation water was) $80-90 \%$, PPV. Soaking of the soil was no more than $30-50 \mathrm{~cm}$ (most of the water $-20 \mathrm{~cm}$ ). Yield was $14-17 \mathrm{~kg} / \mathrm{ha}$. In 2005 , on top of the 0.6 hectare plot was heldlate spring irrigation (groundwater level here was deep, and the rest of the plot ranged from 2 to $6.5 \mathrm{~m}$ ) [9]. Soil moisture reserves were insufficient to get germination, so Peres was held in mid-May after spending Preplan watering norm $250-300 \mathrm{~m}^{3} / \mathrm{ha}$.

Study on dozhdevaniju at the site showed that the intensity of the rain at IDAD $(3 \mathrm{~mm} / \mathrm{min})$ more speed the absorption of water into the soil study. Therefore, when submitting a $500 \mathrm{~m}^{3} / \mathrm{HA}$ formed puddles and surface onto the object. Reset amounted 20$30 \%$, resulting in uneven wetting. In the beginning of vegetation due to timely treatments surface declined reset (until 8-10). When processing of crops ceased, reset again reached $16-17 \%$.

Promachivanie soil when watering does not exceed $30-60 \mathrm{~cm}$. More impregnation and better moisture uniformity in these conditions is achieved under irrigation norms more than 300 $400 \mathrm{~m}^{3} /$ ha. When such rules about $60-70 \%$ of water remains in the top bar $(20 \mathrm{~cm})$ layer, and the plants are not totally moisture $[1,2,3]$.

Observed disadvantages sprinkling apparatus IDAD, when availability of irrigation network, impassable for the mechanisms in soil treatment. In doing so, found that sprinklers and roads along them occupy $6 \%$ of the area; water loss in sprinklers in Guba RCAN amounted $25-30 \%$ at $1 \mathrm{~km}$ and in Terter AIA -15\% $[4,5]$.

The distribution of water in the micro-irrigation is shown in Table 2\&3. While the greatest losses occurred in the discharge 
and evaporation. Balance of water when sprinkling the plots presented in table.3.Irrigation norms for different soils and

slopes where runoff begins, are shown in the Table 4.

Table 2: The conditions of sprinkling irrigation apparatus IDAD on territory of Guba RANN, irrigation of orchards on the territory of the AIA Sri "Agriculture" in the Terter district, Sarydzhaly sugar beets and soybeans, Ganja RACN in PIC. Bagmanly orchards and vineyards.

\begin{tabular}{|c|c|c|c|}
\hline Indicators & “Guba RACS" & "Terter RACS" & "Gyandja"RACS \\
\hline Type of soil & Loess-like loam & Galechnikovo-shhebenchatye (low-power) & Loess-like loam \\
\hline Maximum field moisture capacity, $\mathrm{m}^{3} / \mathrm{ha}$ (SWP) & 2970 & 1100 & 2500 \\
\hline Water permeability in the 1 -hour, $\mathrm{m} / \mathrm{h}$ & $0,03-0,05$ & 0.06 & 0.04 \\
\hline Biases(Distortions) & $0,001-0,0001$ & $0,02-0,03$ & $0,004-0,007$ \\
\hline Ground water depth, m & $1-4$ & more than 10 & $2.5-7-10$ \\
\hline Mineralized. g/l & $3-10$ & & $13-14$ \\
\hline Superficial reset with Irrigated plot, \%. & No & up to 30 & maximum 10-20 \\
\hline Moist-armed irrigation and leaching $\mathrm{m}^{3} / \mathrm{ha}$ & $\begin{array}{c}\text { Are held in winter } \\
2500-3000\end{array}$ & Conduct is inappropriate & $\begin{array}{c}\text { Conducted in the } \\
\text { pozdnevesen-period } 1500\end{array}$ \\
\hline Productivity, centner/ha & $30-40$ & $5-10$ & $15-20$ \\
\hline
\end{tabular}

Table 3: Balance of water when sprinkling on plots of Terter and Ganja RACN.

\begin{tabular}{|c|c|c|c|c|}
\hline \multirow{2}{*}{ Balance sheet items } & \multicolumn{2}{|c|}{ Gandja RACS } & \multicolumn{2}{c|}{ Terter RACS } \\
\cline { 2 - 5 } & $\mathbf{m}^{\mathbf{3}} \mathbf{h a}$ & $\mathbf{\%}$ & $\mathbf{m}^{\mathbf{3}} \mathbf{h} \mathbf{h}$ & $\mathbf{\%}$ \\
\hline Parish & 644 & 100 & 693.7 & 100 \\
\hline Total & 644 & 100 & 693.7 & 100 \\
\hline Including: & & & & \\
\hline filtering into the soil & 16.2 & 2.6 & 55.7 & 8.0 \\
\hline residual volume & 7.1 & 1.1 & 10.0 & 1.4 \\
\hline $\begin{array}{c}\text { Evaporation of falling drops } \\
\text { rain on the land }\end{array}$ & 81.2 & 12.6 & 88 & 12.7 \\
\hline Reset from the field & 86.5 & 13.4 & 162 & 23.4 \\
\hline Left on the field & 453 & 70.3 & 378 & 54.5 \\
\hline
\end{tabular}

According to BH Aliyeva, Surface discharge to the zone of the Guba RKNN, when the irrigation sabers of apple experimental sites are up to August $7-8 \%$ and $20 \%$ in August, which is Table 4: Irrigation norm ( $\mathrm{m}^{3} / \mathrm{ha}$ ) before the advent of the runoff on the results of the studies in the regions of Guba-Khachmaz and Ganja-Gazakh zone.

\begin{tabular}{|c|c|c|c|c|}
\hline \multirow{2}{*}{ Soil } & \multicolumn{3}{|c|}{ Biases } \\
\cline { 2 - 5 } & \multicolumn{2}{|c|}{$\mathbf{0 , 0 0 0 2 - 0 , 0 0 0 5}$} & First Watering & 0,002-0,007 \\
\cline { 2 - 5 } & First Watering & The Last Watering & 400 & 170 \\
\hline Supeschanaja & 450 & 230 & 290 & 100 \\
\hline Legkosuglinistaja & 340 & 150 & 170 & 80 \\
\hline Srednesuglinistaja & 290 & 90 & & \\
\hline
\end{tabular}

Production mikro- sprinkler experiments were carried out on the territory of Zakatali district. Re-equip IDAD type tests, and the MDP, we found that groundwater level in deep and complex relief application on tobacco irrigation IDAD, corn, Apple tree, etc. more promising than others, the dominant traditional methods of irrigation $[4,10]$.

The test results confirmed that, to reduce the intensity of rain on a rain showerhead apparatus desirable installation of special nozzles for sprinkling vibratory to $40-50 \mathrm{~m}$ range and additional confirmed by the results of studies submitted in 2005-2009 years. It should be noted that the results of the study in the Terter region on small slopes and fertile soils, where the annual leveling of the margin, after feeding $350-400 \mathrm{~m}^{3} /$ ha on the surface of the fields, puddles appear $[1,2,4,11]$.

Small irrigation norms (prior to the formation of runoff) required a large number of irrigations. So, in Shamakhi district in experiments conducted by OJeB Menia Shemakha Erosion and irrigation (4.8 hectares) on heavy soils in deep groundwater occurrence at the same norm $\left(7000-7500 \mathrm{~m}^{3} / \mathrm{ha}\right)$, the number of irrigations mikro- sprinkler (42-53) has been significantly more than crop furrow (6-8). To combat the crust and seal required to dramatically increase the number of between rows treatments (up to 10), which prevented the complete destruction of the Peel around the stem. Shallow and uneven soil wetting and untimely processing of crops led when sprinkling a marked reduction of the harvest $[4,12]$. supplements for regulation device layer rain, contributing to the SAP pressure port of the pump.

All this made it possible to reduce the intensity of the rain and give irrigation norms $600-700 \mathrm{~m}^{3} /$ ha (where the daily mode) without significant surface relief and soil erosion. These activities can reduce runoff, but it reduces crop productivity. However, difficult and device sprinklers with greater intensity of water within $800-1000 \mathrm{~m}^{3} / \mathrm{ha}$, which require considerable planning work. 
Proposed by nozzles installed at the sprinkler unit IDAD, have a relatively low intensity rain, because of the desire to create a microclimate on plants with low water consumption and limited irrigation geometry plot [4]. Experience shows that with increasing working width could reduce the intensity of rain, while maintaining productivity.

The experimental work carried out by us in the objects of study in Shamakhi, the Tartar, Zagatala, Guba and Ganja on irrigation of soybean, sugar beet, maize and tobacco, allow you to give an estimated average intensity of rain $(\mathrm{mm} / \mathrm{min})$ under irrigation standards of $300-500 \mathrm{~m}^{3} /$ ha depending on soil: Sandy-0.3-0.4, light loamy-0.2-0.3, middle and heavy loam-0.10.2 .

Studies have shown that extensive production verification of this irrigation technology, taking into account the recommended intensity of rain, will clarify the technical-economical indicators and conditions for the use of micro-irrigation $[2,11]$.

The study found that the discrepancy in the intensity of rain water into the soil absorption speed, education and surface soil erosion, uneven and shallow soaking, imperfection of open irrigation network in surface irrigation, the need for different ways of watering during the vegetative and outside the vegetative periods, low coefficient of land use, the high cost of irrigation and other features are, to a certain extent, in contradiction with the requirements for agricultural irrigation technique for arable crops in the zone of deep groundwater $[4,6,9]$.

The analysis showed that irrigation with micro-irrigation could also find distribution in the context of a close non-saline groundwater depth. In deep groundwater, level can achieve high yields of crops, however, techno-economic indicators at this level of development and re-equip the existing socio-economic living conditions of farmers, etc. farms are less favorable compared with surface irrigation by furrows $[2,4]$. Further improvement of sprinkling with higher technical and economic indicators might expand irrigated area micro-irrigation to irrigated agriculture mining conditions in the Republic.

\section{References}

1. Alekperov KA (1980) Soil-erosion map in land protection. Moscow.

2. Aliyev BH, Desertification in Azerbaijan solutions, Zia-Baku, Nurlan, Azerbaijan.

3. Aliyev GA (1959) The Soil of Azerbaijan. In: IZD-vo Volobuev Vr (Ed.), Azeri the USSR, Azerbaijan, p. 122.

4. Aliyev BH, Aliyev HA (2000) The problem of erosion in Azerbaijan and ways of its solution. ZIMA -CPI Nurlan, Baku, Azerbaijan p. 122.

5. Armand DL (1956) Anthropogenic erosion processes. In the book. Agriculture and combating erosion, Moscow.

6. Babayeva KM (1995) Influence of simple and complex mineral fertilizers and planting alfalfa on fertility restoration of eroded soils of the Southeastern slope of the Greater Caucasus. AVT Dees Baku, Azerbaijan.

7. Bennett HH (1958) Basis for soil protection (translated from English).

8. Grossgeym AA (1948) Vegetation of the Caucasus. IZD-vo «Moscow society of naturalists, Moscow.

9. Guseinov AA (1991) Effectiveness of surface improvement of eroded pastureland. All-Union Conference. Dushanbe, p. 1.

10. Zaslavsky NM (1969) To the draft classification of soils in powers of erosion. Sat. materials by the method of soil-erosion mapping erosive events. Moscow.

11. Zaslavsky NM (1983) Erosion science.

12. Ibrahimov AA, Mapping of eroded soils on agricultural lands, for example, The USSR, Dashkesan district of Azerbaijan.

13. Ibrahimov AA (2000) Agri-environmental peculiarity of eroded soils of Azerbaijan. Materials for the study of the processes of erosion and irrigation and soil conservation in Azerbaijan. Baku, Azerbaijan.

14. Ibragimov (1972) Mapping of eroded soils on agricultural economic land (for example, Dashkesan district of Azerbaijan SSR). Issues of methodology for land cover mapping erosive. Moscow.

\begin{tabular}{|l|}
\hline \multicolumn{1}{|c|}{ Your next submission with Juniper Publishers } \\
will reach you the below assets \\
- Quality Editorial service \\
- Swift Peer Review \\
- Reprints availability \\
- E-prints Service \\
- Manuscript Podcast for convenient understanding \\
- Global attainment for your research \\
- Manuscript accessibility in different formats \\
( Pdf, E-pub, Full Text, Audio) \\
- Unceasing customer service \\
Track the below URL for one-step submission \\
https://juniperpublishers.com/online-submission.php \\
\hline
\end{tabular}

